\title{
Vegetative Growth Responses of Citrus Nursery Trees to Various Growth Retardants
}

\author{
Smit le Roux ${ }^{1}$ and Graham H. Barry ${ }^{2,3,4}$
}

AdDitional INDEX wORDs. gibberellin-biosynthesis inhibitors, paclobutrazol, prohexadione-calcium, rind color, uniconazole

SUMMARY. As part of a larger study to improve rind color of citrus (Citrus spp.) fruit, this initial study was conducted to determine the concentration of various gibberellin-biosynthesis inhibitors required to elicit a biological response in citrus trees, as measured by vegetative growth. Paclobutrazol and $\mathrm{GA}_{3}$ were included as control treatments at concentrations known to elicit growth-retarding or growthpromoting effects, respectively. Repeated $(\times 4)$ foliar applications of $\mathrm{GA}_{3}$ (at 64 ppm) increased growth of 'Eureka' lemon (Citrus limon) shoots by 63\%, with no significant effect on rootstock and scion diameters. Repeated foliar applications of prohexadione-calcium (ProCa) at various concentrations $(100,200,400$, or 800 ppm) as well as uniconazole (at 500 or $1000 \mathrm{ppm}$ ) and paclobutrazol (at $0.25 \%$ ) had no effect on rootstock or scion diameters 8 months after the first application. The high concentrations of ProCa $(800 \mathrm{ppm})$ and uniconazole $(1000 \mathrm{ppm})$, and the paclobutrazol treatment $(0.25 \%)$ reduced shoot length compared with the control. Uniconazole at $1000 \mathrm{ppm}$ resulted in the most growth retardation, which resulted in $34 \%$ shorter shoot length than the control. Although the number of nodes on the longest shoot did not differ from the untreated control, internode length differed significantly among treatments. ProCa at 400 and $800 \mathrm{ppm}$, uniconazole at 1000 ppm, and paclobutrazol at $\mathbf{0 . 2 5 \%}$ significantly reduced internode length relative to the control by $31 \%, 56 \%, 50 \%$, and $28 \%$, respectively. Vegetative growth of 'Eureka' lemon nursery trees was retarded following the repeated $(\times 4)$ foliar application of gibberellin-biosynthesis inhibitors. ProCa at 400 to $800 \mathrm{ppm}$ and uniconazole at $1000 \mathrm{ppm}$ were identified as prospective treatments for further field studies to test their effects on rind color enhancement of citrus fruit.

A $s$ part of a larger study to improve rind color of citrus fruit, this initial study was conducted to determine the concentration of various gibberellin-biosynthesis inhibitors required to elicit a biological response in citrus trees as measured by vegetative growth. Goldschmidt (1988) hypothesized that factors contributing to invigorating growing conditions are antagonistic to optimal rind color development.

The vegetative growth of citrus trees is stimulated by various exogenous factors, viz. high temperature,

This study was made possible by partial funding from Citrus Growers' Association of Southern Africa, Citrus Research International, the National Research Foundation (grant no. NRF 2046844), and Du Roi Nursery.

We thank Willem van Kerwel for technical assistance and Nucellar Nursery for providing the trees in this study

${ }^{1}$ Department of Horticultural Science, Stellenbosch University, P. Bag X01, Matieland 7602, Stellenbosch, South Africa

${ }^{2}$ Citrus Research International, Department of Horticultural Science, Stellenbosch University, P. Bag X01, Matieland 7602, Stellenbosch, South Africa

${ }^{3}$ Current address: GCM Variedades Vegetales AIE, Valencia, Spain.

${ }^{4}$ Corresponding author. E-mail: ghbarry@gmail.com. high light intensity, nitrogen, and water, as well as endogenous hormones, viz. gibberellins and cytokinins. Young leaves and fruit are major sites of gibberellin biosynthesis (Salisbury and Ross, 1992; Spiegel-Roy and Goldschmidt, 1996). High endogenous gibberellin concentrations enhance stem elongation (Salisbury and Ross, 1992) and delay rind color development of citrus fruit (GarciaLuis et al., 1985).

Growth retardants, some of which are gibberellin-biosynthesis inhibitors, reduce vegetative growth in plants by disrupting gibberellin biosynthesis (Smeirat and Qrunfleh, 1989). Aron et al. (1985) demonstrated that when paclobutrazol (Cul$\operatorname{tar}{ }^{\circledR}$; Syngenta Crop Protection, Basel, Switzerland) was applied at 1 $\mathrm{g} \cdot \mathrm{L}^{-1}$ on 'Minneola' tangelo (Citrus reticulata $\times$ Citrus paradisi) trees just before the onset of the summer flush, it reduced shoot length, internode length, and the number of shoots developed by $41 \%, 76 \%$, and $44 \%$, respectively. Similarly, Delgado et al. (1986) showed that paclobutrazol reduced internode length, and hence shoot length, of 'Valencia' sweet orange (Citrus sinensis) in Cuba. Uniconazole (Sunny®; Valent BioSciences, Chicago) reduced shoot length, number of lateral shoots per terminal, number of nodes per terminal, and internode length in 'Wichita' pecan (Carya illinoinensis) (Graham and Storey, 2000) and 'Cleopatra' mandarin (C. reticulata) (Wheaton, 1989) trees. ProCa (Regalis ${ }^{\circledR}$ and Apogee ${ }^{\circledR}$; BASF, Ludwigshafen, Germany) is used on apple (Malus $\times$ domestica) and pear (Pyrus communis) fruit trees to reduce and control vegetative growth (Miller, 2002). Costa et al. (2001) reported that applications of $100 \mathrm{ppm}$ ProCa significantly reduced shoot growth and increased fruit size in pears. ProCa acts primarily as a gibberellinbiosynthesis inhibitor, especially $3 \beta$-hydroxylation of $\mathrm{GA}_{20}$ to $\mathrm{GA}_{1}$ (Nakayama et al., 1992; Rademacher, 2001). Stover et al. (2004) found that two 500 ppm ProCa applications reduced the vegetative growth of six citrus genotypes tested by $\approx 40 \%$.

In contrast to the affects of gibberellin-biosynthesis inhibitors on vegetative growth, their effects on rind color enhancement of citrus fruit are not well known. Monselise and coworkers (1976) reported that paclobutrazol contributed to the acceleration of chlorophyll degradation of sweet orange. Gilfillan and Lowe (1985) demonstrated that paclobutrazol increased 'Satsuma' mandarin (Citrus unshiu) rind color by 1 to 2 color rating units. This result was achieved when paclobutrazol was applied after physiological fruit drop (in November) at $1 \mathrm{~g} \cdot \mathrm{L}^{-1}$, as well as in summer (January and February),

\begin{tabular}{lllc}
\hline $\begin{array}{l}\text { Units } \\
\begin{array}{l}\text { To convert U.S. to SI, } \\
\text { multiply by }\end{array}\end{array}$ & U.S. unit & SI unit & $\begin{array}{l}\text { To convert SI to U.S., } \\
\text { multiply by }\end{array}$ \\
\hline 0.3048 & $\mathrm{ft}$ & $\mathrm{m}$ & 3.2808 \\
2.54 & inch(es) & $\mathrm{cm}$ & 0.3937 \\
25.4 & inch $(\mathrm{es})$ & $\mathrm{mm}$ & 0.0394 \\
0.001 & $\mathrm{ppm}$ & $\mathrm{g} \cdot \mathrm{L}^{-1}$ & 1000 \\
1 & $\mathrm{ppm}$ & $\mathrm{mg} \cdot \mathrm{L}^{-1}$ & 1
\end{tabular}


and suggests that paclobutrazol suppressed the early summer growth flush (November-December), which might be more important for rind color development than the late summer flush (January-February). Monselise (1986) mentioned that paclobutrazol caused a more rapid change of rind color in 'Topaz' tangor $(C$. reticulata $\times$ C. sinensis), an Israeli selection of 'Ortanique' tangor. Preliminary results by Barry and Van Wyk (2004) showed that when ProCa was applied 2 weeks before anticipated harvest at $100 \mathrm{ppm}$ to 'Navelina Navel' sweet orange, rind color was improved as a result of chlorophyll degradation and carotenoid biosynthesis. No other reports on the possible affect of gibberellinbiosynthesis inhibitors on rind color enhancement of citrus fruit were found.

The principal objective of this study was to determine the concentration of various gibberellin-biosynthesis inhibitors required to retard shoot growth in citrus nursery trees. This information could then be used in field studies to test the effects of gibberellinbiosynthesis inhibitors on rind color enhancement of citrus fruit.

\section{Materials and methods}

Plant material and site. During the 2005-06 summer growing season, 108 potted nursery trees of 'Eureka' lemon budded on 'X639' rootstock ['Cleopatra' mandarin $\times$ trifoliate orange (Poncirus trifoliata)] of similar size and with at least three strong primary branches were selected at Nucellar Nursery, Simondium, Western Cape province, South Africa (lat. $33^{\circ} 50^{\prime} \mathrm{S}$, long. $18^{\circ} 58^{\prime} \mathrm{E}, 160 \mathrm{~m}$ altitude). These trees were 21 months old at the start of the experiment.

Treatments applied. Potted nursery trees were randomly allocated to treatments that were applied as foliar sprays, viz. untreated control; $\mathrm{GA}_{3}$ (ProGibb ${ }^{\circledR}$, Valent BioSciences) at 64 ppm a.i.; ProCa at 100, 200, 400 , or $800 \mathrm{ppm}$; uniconazole at 500 or $100 \mathrm{ppm}$; and paclobutrazol at $0.25 \%$. Paclobutrazol and $\mathrm{GA}_{3}$ were included as control treatments at concentrations known to elicit growthretarding and growth-promoting effects, respectively. Kaolin particle film (Surround ${ }^{\circledR}$ WP Crop Protectant; Engelhard, Iselin, NJ) at 2 ppm a.i. was applied together with all treatments to easily distinguish new growth flushes throughout the assessment period. All treatments were applied four times on 15 Nov. 2005 , 27 Dec. 2005, 16 Feb. 2006, and 31 Mar. 2006, and these application dates were planned to coincide with various growth flushes during the summer growing season.

Data collection. Rootstock and scion diameters were measured $2 \mathrm{~cm}$ below and $3 \mathrm{~cm}$ above the bud union, at the start of the experiment (15 Nov. 2005), 6 weeks thereafter (27 Dec. 2005), and at the end of the experiment (20 July 2006). Three shoots per tree were selected, marked, and their length was measured at the start of the experiment. Thereafter, only the length of the new growth was measured and internodes were counted at each assessment date. The purpose of this study was not to quantify the optimal concentration of growth retardant required to achieve maximum growth retardation, but rather to determine at what concentration various gibberellin-biosynthesis inhibitors caused a vegetative growth response in citrus nursery trees. Therefore, and because all shoots did not flush and grow out, data analysis was done on the longest shoot to quantify the treatment effects on growth retardation.

Table 1. Mean rootstock and scion diameters of citrus nursery trees of 'Eureka' lemon budded onto 'X639' rootstock after treatment with GA $_{3}$, prohexadione-calcium (ProCa), uniconazole, and paclobutrazol to determine the concentration of various gibberellin-biosynthesis inhibitors required to retard shoot growth in citrus nursery trees. Measurements were made at the start of the experiment (15 Nov. 2005), 6 weeks thereafter (27 Dec. 2005), and at the end of the experiment (20 July 2006).

\begin{tabular}{|c|c|c|c|c|c|c|}
\hline \multirow[b]{2}{*}{ Treatment (a.i. $)^{\mathrm{z}}$} & \multicolumn{3}{|c|}{ Rootstock diam $(\mathrm{mm})^{\mathrm{z}}$} & \multicolumn{3}{|c|}{ Scion diam $(\mathrm{mm})$} \\
\hline & $\begin{array}{c}15 \text { Nov. } \\
2005\end{array}$ & $\begin{array}{c}27 \text { Dec. } \\
2005\end{array}$ & $\begin{array}{c}20 \text { July } \\
2006\end{array}$ & $\begin{array}{c}15 \text { Nov. } \\
2005\end{array}$ & $\begin{array}{c}27 \text { Dec. } \\
2005\end{array}$ & $\begin{array}{c}20 \text { July } \\
2006\end{array}$ \\
\hline Control & $14.3 \mathrm{NS}^{\mathrm{y}}$ & 13.9 NS & $14.5 \mathrm{NS}$ & $11.1 \mathrm{bc}$ & $11.0 \mathrm{bc}$ & $11.8 \mathrm{NS}$ \\
\hline $\mathrm{GA}_{3} 64 \mathrm{ppm}$ & 14.6 & 14.2 & 15.3 & $12.3 \mathrm{a}$ & $11.5 \mathrm{abc}$ & 12.1 \\
\hline ProCa 100 ppm & 14.1 & 14.2 & 14.4 & $10.9 \mathrm{c}$ & $11.2 \mathrm{bc}$ & 11.2 \\
\hline ProCa 200 ppm & 14.3 & 14.2 & 14.5 & $11.5 \mathrm{abc}$ & $11.0 \mathrm{bc}$ & 11.8 \\
\hline ProCa 400 ppm & 15.4 & 15.3 & 15.7 & $11.8 \mathrm{abc}$ & $11.3 \mathrm{bc}$ & 11.6 \\
\hline ProCa 800 ppm & 13.4 & 13.5 & 14.2 & $11.2 \mathrm{bc}$ & $10.7 \mathrm{c}$ & 11.3 \\
\hline \multicolumn{7}{|l|}{ Uniconazole } \\
\hline $500 \mathrm{ppm}$ & 15.0 & 15.3 & 15.6 & $12.1 \mathrm{ab}$ & $11.9 \mathrm{ab}$ & 12.2 \\
\hline \multicolumn{7}{|l|}{ Uniconazole } \\
\hline $1000 \mathrm{ppm}$ & 14.8 & 14.6 & 15.1 & $11.4 \mathrm{abc}$ & $11.0 \mathrm{bc}$ & 11.4 \\
\hline \multicolumn{7}{|l|}{ Paclobutrazol } \\
\hline $0.25 \%$ & 14.3 & 14.8 & 15.3 & $12.2 \mathrm{a}$ & $12.4 \mathrm{a}$ & 12.2 \\
\hline$P$ value & 0.2780 & 0.3159 & 0.3179 & 0.0430 & 0.0482 & 0.2207 \\
\hline $\operatorname{LSD}^{x}$ & 1.45 & 1.60 & 1.41 & 1.00 & 1.02 & 0.91 \\
\hline
\end{tabular}

${ }^{\mathrm{z}} 1 \mathrm{ppm}=1 \mathrm{mg} \cdot \mathrm{L}^{-1}, 1 \mathrm{~mm}=0.0394$ inch.

${ }^{y}$ Means within columns followed by different letters are significantly different at $P \leq 0.05$; NS = nonsignificant. ${ }^{\mathrm{L}}$ Least significant difference. 
(i.e., 8 months), there was too little time for a treatment response in rootstock and scion diameters, although differences would be expected with a longer-term study (Smeirat and Qrunfleh, 1989).

Shoot length of the longest shoot was $63 \%$ longer for the $\mathrm{GA}_{3}$ treatment than for the control (Fig. 1), which confirms previous reports that $\mathrm{GA}_{3}$ applied at 64 ppm stimulates citrus shoot growth (Mudzunga, 2000 ). This response is not unexpected given the role of gibberellins in enhancing stem elongation (Salisbury and Ross, 1992). In contrast, shoot length of the trees that received the high concentrations of ProCa (800 ppm) and uniconazole (1000 ppm), and the paclobutrazol treatment
$(0.25 \%)$, were shorter than that of the control (Fig. 1). The 1000 ppm uniconazole treatment had $34 \%$ shorter shoot length than the control. Shoot length of the other treatments did not differ from that of the control (Fig. 1).

Although the number of nodes on the longest shoot did not differ in any of the treatments from the untreated control (Fig. 2), internode

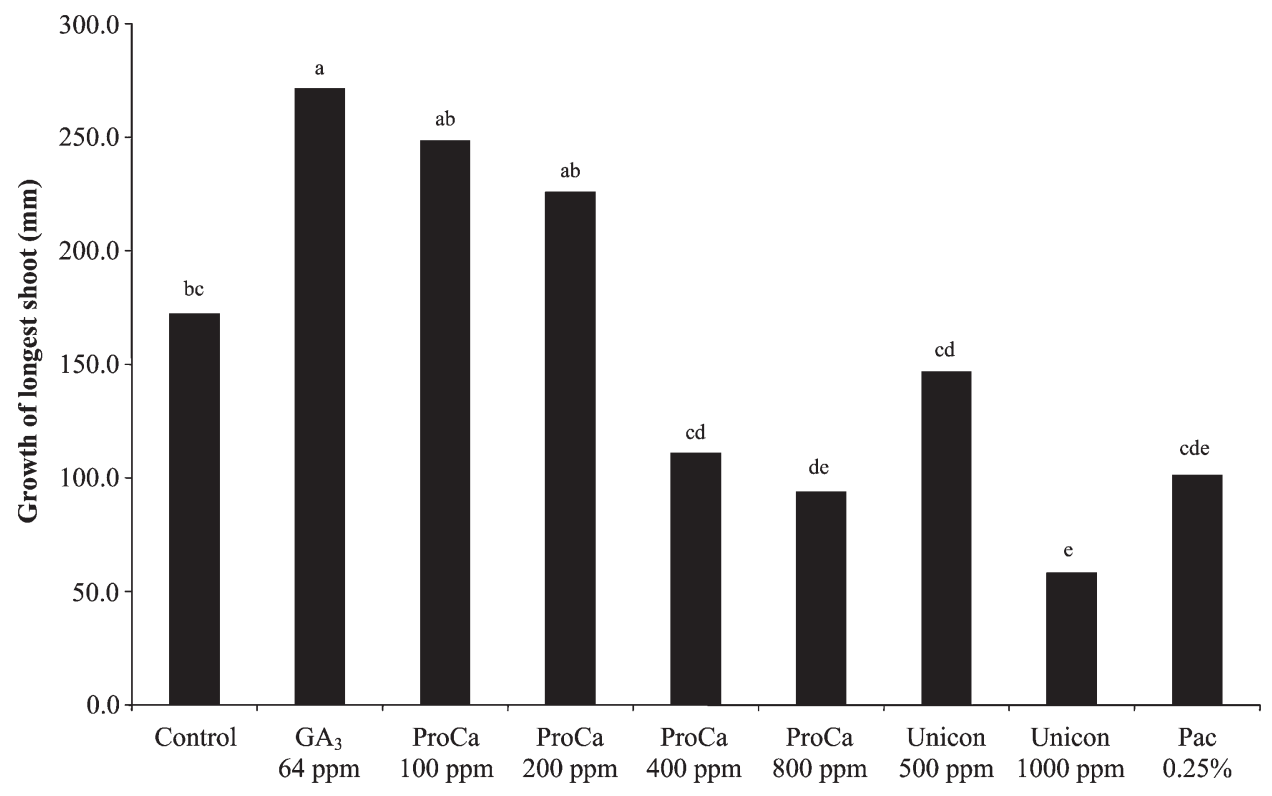

Fig. 1. Shoot length of the longest shoot of 'Eureka' lemon nursery trees at the end of the experiment on 20 July 2006 after treatment with $\mathrm{GA}_{3}$, prohexadione-calcium (ProCa), uniconazole (Unicon), and paclobutrazol (Pac) to determine the concentration of various gibberellin-biosynthesis inhibitors required to retard shoot growth in citrus nursery trees. Means followed by a different letter are significantly different at $P \leq 0.10$ (least significant difference $=76.7$ ); $1 \mathrm{ppm}=1 \mathrm{mg} \cdot \mathrm{L}^{-1}$, $1 \mathrm{~mm}=0.0394$ inch.

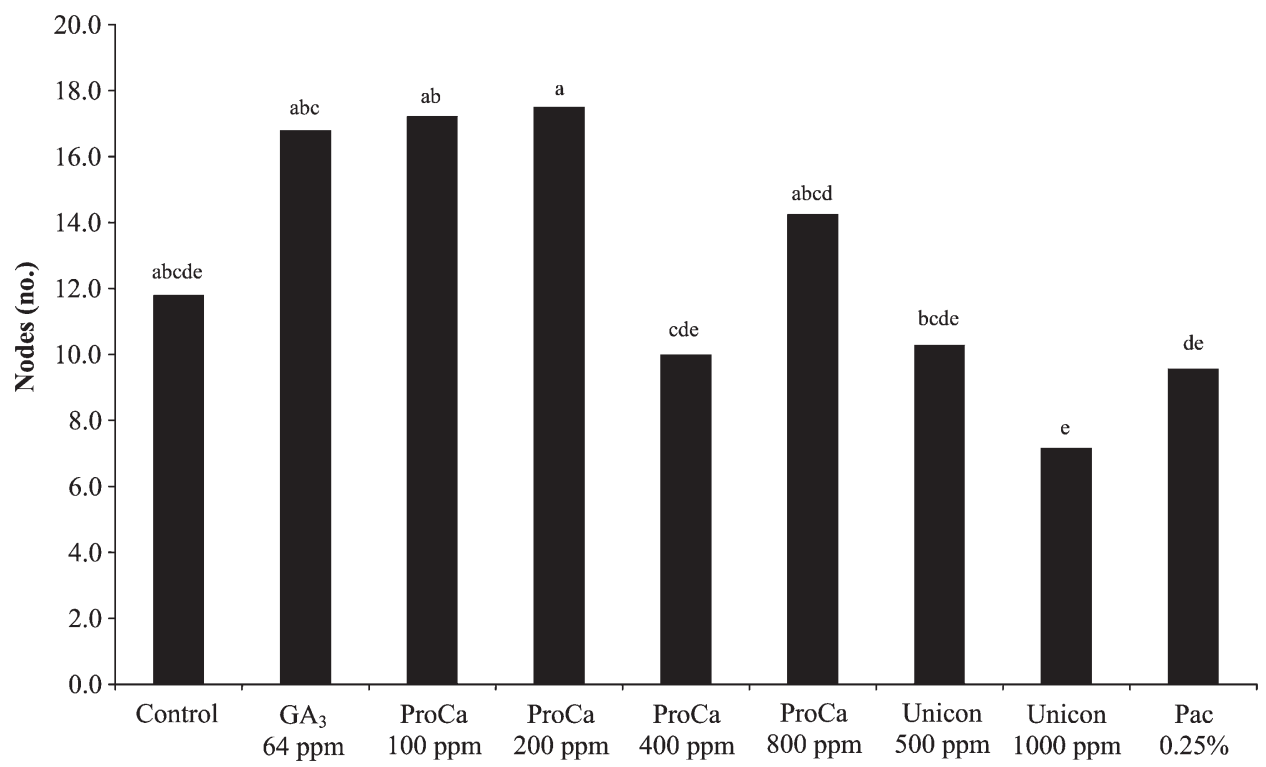

Fig. 2. Number of nodes on the longest shoot of 'Eureka' lemon nursery trees the end of the experiment on 20 July 2006 after treatment with $\mathrm{GA}_{3}$, prohexadione-calcium (ProCa), uniconazole (Unicon), and paclobutrazol (Pac) to determine the concentration of various gibberellin-biosynthesis inhibitors required to retard shoot growth in citrus nursery trees. Means followed by a different letter are significantly different at $P \leq 0.05$ (least significant difference $=6.96$ ); $1 \mathrm{ppm}=1 \mathrm{mg} \cdot \mathrm{L}^{-1}$. 


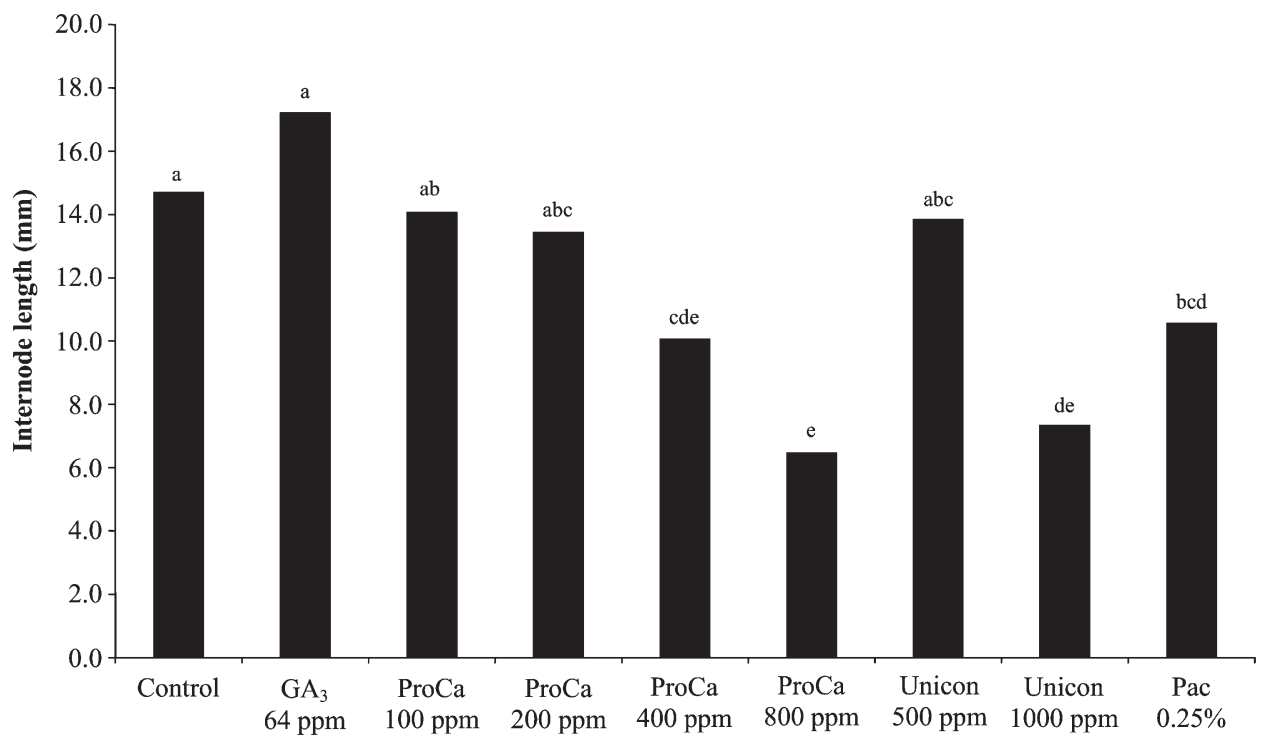

Fig. 3. Internode length of the longest shoot of 'Eureka' lemon nursery trees the end of the experiment on 20 July 2006 after treatment with $\mathrm{GA}_{3}$, prohexadione-calcium (ProCa), uniconazole (Unicon), and paclobutrazol (Pac) to determine the concentration of various gibberellin-biosynthesis inhibitors required to retard shoot growth in citrus nursery trees. Means followed by a different letter are significantly different at $P \leq 0.05$ (least significant difference $=3.87) ; 1 \mathrm{ppm}=1 \mathrm{mg} \cdot \mathrm{L}^{-1}, 1 \mathrm{~mm}=$ 0.0394 inch.

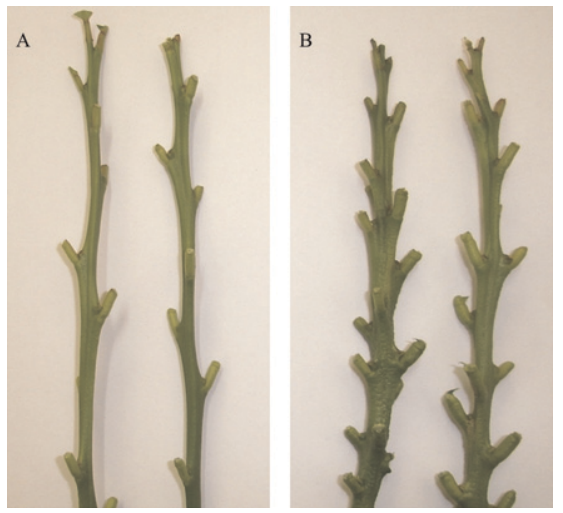

Fig. 4. Photographs of 'Eureka' lemon shoots that illustrate the effect of growth retardants on vegetative growth. (A) untreated control (internode length $=14.7 \mathrm{~mm}$ ); (B) 400 ppm prohexadione-calcium (ProCa) (internode length $=10.1 \mathrm{~mm}$ ). Note the shortening of internode length by $>\mathbf{3 0} \%$ in the Pro-Ca treatment compared with the untreated control treatment; $1 \mathrm{~mm}=\mathbf{0 . 0 3 9 4} \mathrm{inch}$, $1 \mathrm{ppm}=1 \mathrm{mg} \cdot \mathrm{L}^{-1}$. (To view this figure in color, please view the paper online through the ASHS website: ashs.org.)

length differed significantly among treatments (Fig. 3). ProCa at 400 and $800 \mathrm{ppm}$, uniconazole at 1000 $\mathrm{ppm}$, and paclobutrazol at $0.25 \%$ reduced internode length relative to the control by $31 \%, 56 \%, 50 \%$, and $28 \%$, respectively (Figs. 3 and 4 ). In this study, the cause of shorter shoot length was not due to fewer nodes, but rather due to shorter internode length (Fig. 4).

These results compare favorably with those in previous reports on the effects of gibberellin-biosynthesis inhibitors on citrus growth. For example, vegetative growth retardation following paclobutrazol treatment was achieved with 'Mexican' lime (Citrus aurantifolia) (Medina-Urrutia and Buenrostro-Nava, 1995), lemon (Harty and van Staden, 1988; Smeirat and Qrunfleh, 1989), 'Valencia' sweet orange (Delgado et al., 1986), and 'Minneola' tangelo (Aron et al., 1985; Greenberg et al., 1993); uniconazole reduced shoot length of sour orange (Citrus aurantium) (Swietlik, 1986) and 'Cleopatra' mandarin seedlings (Wheaton, 1989); and Stover et al., (2004) showed that two $500 \mathrm{ppm}$ ProCa applications reduced the vegetative growth of six citrus genotypes tested.

In conclusion, vegetative growth of 'Eureka' lemon nursery trees was retarded following the repeated foliar application of gibberellin-biosynthesis inhibitors. Because it is unlikely that paclobutrazol would be registered on citrus due to its persistence in the environment and the plant (Goulston and Shearing, 1985), ProCa at 400 to $800 \mathrm{ppm}$ and uniconazole at $1000 \mathrm{ppm}$ are prospective treatments for further field studies to test their effects on rind color enhancement of citrus fruit.

\section{Literature cited}

Aron, Y., S.P. Monselise, R. Goren, and J. Costo. 1985. Chemical control of vegetative growth in citrus trees by paclobutrazol. HortScience 20:96-98.

Barry, G.H. and A.A. Van Wyk. 2004. Novel approaches to rind colour enhancement of citrus. Proc. Intl. Soc. Citriculture 3:1076-1079.

Costa, G., C. Andreotti, F. Bucchi, E. Sabatini, C. Bazzi, and S. Malaguti. 2001. Prohexadione-Ca (Apogee $\left.{ }^{\circledR}\right)$ : Growth regulation and reduced fire blight incidence in pear. HortScience 36:931-933.

Delgado, R., R. Casamayor, J.L. Rodriguez, P. Cruz, and R. Fajardo. 1986. Paclobutrazol effects on oranges under tropical conditions. Acta Hort. 179:537-544.

Garcia-Luis, A., M. Agusti, V. Almela, E. Romero, and J.L. Guardiola. 1985. Effects of gibberellic acid on ripening and peel puffing in Satsuma mandarin. Scientia Hort. 27:75-86

Gilfillan, I.M. and S.J. Lowe. 1985. Fruit colour improvement in Satsumas with paclobutrazol and ethephon: Preliminary studies. Citrus J. 5:4-8.

Goldschmidt, E.E. 1988. Regulatory aspects of chloro-chromoplast interconvensions in senescing Citrus fruit peel. Israeli J. Bot. 47:123-130.

Goulston, G.H. and S.J. Shearing. 1985. Review of the effects of paclobutrazol on ornamental pot plants. Acta Hort. 167:339348 . 
Graham, C.J. and J.B. Storey. 2000. Method of application of uniconazole affects vegetative growth of pecan. HortScience 35:1199-1201.

Greenberg, J., E.E. Goldschmidt, and R. Goren. 1993. Potential and limitations of the use of paclobutrazol in citrus orchards in Israel. Acta Hort. 329:58-61.

Harty, A.R. and J. van Staden. 1988. Paclobutrazol and temperature effects on lemon. Proc. Sixth Intl. Citrus Congr. p. 343-353.

Medina-Urrutia, V. and M. BuenrostroNava. 1995. Effect of paclobutrazol on vegetative growth, flowering fruit size and yield in Mexican lime (Citrus aurantifolia) trees. Proc. Florida State Hort. Soc. 108:361-364.

Miller, S.S. 2002. Prohexadione-calcium controls vegetative shoot growth in apple. J. Tree Fruit Production 3:11-28.

Monselise, S.P. 1986. Growth retardation of shoot and peel growth in citrus by paclobutrazol. Acta Hort. 179:529-535.
Monselise, S.P., M. Weiser, N. Shafir, R. Goren, and E.E. Goldschmidt. 1976. Creasing of orange peel: Physiology and control. J. Hort. Sci. 51:341-351.

Mudzunga, M.J. 2000. Enhancement of vegetative growth in young citrus plantings. Univ. Stellenbosch, Stellenbosch, South Africa, M.S. Agr. thesis.

Nakayama, I., M. Kobayashi, Y. Kamiya, H. Abe, and A. Sakurai. 1992. Effects of plant-growth regulator, prohexadionecalcium (BX-112), on the endogenous levels of gibberellins in rice. Plant Cell Physiol. 33:59-62.

Rademacher, W. 2001. BAS 12510 W ("Regalis"): General information and biological profile. BASF Global PGR Research and Development, Limburgerhof, Germany.

Salisbury, F.B. and C.W. Ross. 1992. Plant physiology. Wadsworth, Belmont, CA.

Smeirat, N. and M. Qrunfleh. 1989. Effect of paclobutrazol on vegetative and reproductive growth of 'Lisbon' lemon. Acta Hort. 239:261-264.

Spiegel-Roy, P. and E.E. Goldschmidt. 1996. Fruit development and maturation, p. 92-107. In: P. Spiegel-Roy and E.E. Goldschmidt (eds.). Biology of citrus. Cambridge University Press, Cambridge, UK.

Stover, E.W., S.M. Ciliento, and M.E. Myers. 2004. Response of six citrus genotypes to prohexadione-Ca. Plant Growth Regulat. Soc. Amer. 32:86.

Swietlik, D. 1986. Effect of gibberellin inhibitors on growth and mineral nutrition of sour orange seedlings. Scientia Hort. 29:325-333.

Wheaton, T.A. 1989. Triazole bioregulators reduce internode length and increase branch angle of citrus. Acta Hort. 239: 277-280. 